\title{
Effect of Light-Curing Methods on Resin Cement Knoop Hardness at Different Depths
}

\author{
Mário Alexandre Coelho SINHORETI ${ }^{1}$ \\ Izabella Paola MANETTA ${ }^{1}$ \\ Rubens Nisie TANGO ${ }^{2}$ \\ Nelson Tetsu IRIYAMA ${ }^{1}$ \\ Rafael Leonardo Xediek CONSANI ${ }^{3}$ \\ Lourenço CORRER-SOBRINHO ${ }^{1}$ \\ ${ }^{1}$ Dental Materials Area, Department of Restorative Dentistry, School of Dentistry of Piracicaba, \\ State University of Campinas, Piracicaba, SP, Brazil \\ ${ }^{2}$ Dental Materials Area, Department of Dental Materials and Prosthodontics, \\ School of Dentistry of São Jose dos Campos, State University of São Paulo, São Jose dos Campos, SP, Brazil \\ ${ }^{3}$ Prosthodontics Area, Department of Prosthodontics and Periodontics, School of Dentistry of Piracicaba, \\ State University of Campinas, Piracicaba, SP, Brazil
}

\begin{abstract}
This study evaluated, using Knoop hardness test, the polymerization depth of Rely-X dual-cured resin cement activated by chemical reaction alone (control group) or by chemical/physical mode with light curing through a 1.5 -mm-thick ceramic layer (HeraCeram). Bovine incisors had their buccal surface flattened and hybridized. On this surface, a rubber mould (5 mm diameter; $1 \mathrm{~mm}$ high) was bulk filled with cement. Either a polyester strip or a $1.5-\mathrm{mm}$-thick disc of the veneering material was seated over this set. Light curing was performed with either conventional halogen light (QTH; XL2500) for $40 \mathrm{~s}$, light-emitting diode (LED; Ultrablue Is) for $40 \mathrm{~s}$ or xenon plasma arc (PAC; Apollo 95E) for $3 \mathrm{~s}$. In a control group, cement setting occurred by chemical reaction alone. After storage dry in dark $\left(24 \mathrm{~h} / 37^{\circ} \mathrm{C}\right)$, the specimens $(\mathrm{n}=5)$ were sectioned for hardness $(\mathrm{KHN})$ measurements at three depths in a microhardness tester $(50$ gf load/15 s). Data were submitted to ANOVA and Tukey's test $(\alpha=0.05)$. Rely-X cement presented higher Knoop hardness values when the QTH and LED LCUs were used, compared to the control group and PAC. Light curing with PAC resulted in lower hardness compared to the control group. Cement hardness was significantly lower in deeper regions.
\end{abstract}

Key Words: resin cement, hardness, dental porcelain, polymerization.

\section{INTRODUCTION}

The use of resin cements has increased considerably in the last years due to a larger application of indirect restorative materials, such as ceramics. As advantages, these cements present adhesion to substrates due to their compatibility with silane agents and adhesive systems, low solubility, ease of handling and favorable esthetics when used with metal-free ceramic systems. In addition, the use of resin cements may result in higher fatigue compressive strength of all- ceramic crowns compared to glass ionomer and zinc phosphate cements (1).

Despite the variety of currently available cements, there is no ideal material for all clinical situations. Therefore, the choice of the luting agent must rely on its physical, biological and handling properties allied to the characteristics of the prepared tooth and prosthesis (2).

Factors, such as light-curing method and exposure time, use of an indirect restorative material and the luting agent have been shown to influence the final quality of the restorations $(3,4)$. Inlays, onlays, lami-

Correspondence: Prof. Dr. Mário Alexandre Coelho Sinhoreti, Faculdade de Odontologia de Piracicaba, UNICAMP, Área Materiais Dentários, Av. Limeira, 901, 13414-903 Piracicaba, SP, Brasil. Tel:+55-19-2106-5374. Fax: +55-19-2106-5218. e-mail: sinhoret@fop.unicamp.br 
nated veneers and all-ceramic crowns are commonly cemented with dual-cured resin cements because light transmission through indirect restorative materials is critical and the chemical reaction would theoretically guarantee a satisfactory polymerization.

It has been demonstrated that the light transmission spectrum through ceramics is influenced by its thickness, shade and opacity (5). The application of longer light-exposure times results in higher composite resin depth of cure, conversion degree and hardness $(3,6,7)$, which implicates in improved esthetic and mechanical properties (8). According to Tanoue et al. (9), however, this does not apply to light-cured resin cements.

Hardness testing is commonly used as a simple and reliable method to indicate the degree of conversion of resin-based cements (10). The degree of conversion in a polymerization reaction is dependent on the energy delivered during light curing, characterized as the product of light intensity and exposure time (11). Comparison of materials of the same commercial brand has shown that, when light activated, dual-cure resin cements present higher hardness than light-cured materials (3). It has also been found that llight-activated dual-cure resin cements present higher hardness than dual-cure materials that are cured by chemical reaction alone (11). Witzel et al. (11) verified that, when not light activated and associated with one-bottle adhesive systems, dual-cure resin cements produced about 51\% and $64 \%$ lower bond strengths than light-activated dual-cure cements.

Light curing is usually performed with quartz tungsten halogen (QTH) light-curing units (LCUs). Other technologies, such as xenon plasma arc (PAC) and light-emitting diodes (LED) are also available. Although these systems are still being developed, their application has grown considerably. Doubts about the effectiveness of light activation of resin cements with different methods using these LCUs still exist. Thus, the null hypothesis of this study is that similar resin cement hardness is obtained with different LCUs (QTH, PAC and LED) and cement activation modes.

\section{MATERIAL AND METHODS}

Disc-shaped specimens $(1.5 \mathrm{~mm}$ height and 7 mm diameter) were prepared with a feldspathic ceramic (HeraCeram, Heraeus Kulzer, Wehrhein, Germany).
To simulate cementation conditions, the crowns of 120 freshly extracted bovine incisors were removed and embedded in polystyrene resin in plastic moulds, keeping the buccal surface exposed. The buccal surfaces were ground flat under water cooling with \#200, 400- and 600-grit SiC papers (Saint-Gobain, Recife, PE, Brazil) to obtain an exposed dentin area of at least 25 $\mathrm{mm}^{2}$. On this surface, a polyester strip was seated and, over this set, a rubber mould $(1 \mathrm{~mm}$ height and $5 \mathrm{~mm}$ diameter) was bulk filled with cement. Rely-X ARC dual-cured resin cement (3M/ESPE, St. Paul, MN, USA; shade A3) was prepared according to manufacturer's instructions. Another polyester strip was seated over this set and a disc of veneering material was digitally compressed to promote extrusion and removal of excess material. Light curing was performed a conventional QTH LCU (XL 2500; 3M/ESPE; 700 $\mathrm{mW} / \mathrm{cm}^{2}$ ) for $40 \mathrm{~s}$, a LED LCU (Ultrablue Is; DMC Equip. Ltda., São Carlos, SP, Brazil; $440 \mathrm{~mW} / \mathrm{cm}^{2}$ ) for $40 \mathrm{~s}$ and a PAC LCU (Apollo 95E, DMD Equip. Ltd., Westlake Village, CA, USA; $1600 \mathrm{~mW} / \mathrm{cm}^{2}$ ) for $3 \mathrm{~s}$. In a control group, cement setting occurred by chemical reaction alone.

After light curing, the specimens were stored dry in dark at $37^{\circ} \mathrm{C}$ during $24 \mathrm{~h}$. To perform resin cement Knoop hardness measurements, specimens were sectioned longitudinally under water with water-cooled diamond wafer blade (Extec model 12205, Extec Corp., Enfield, CT, USA). The surface obtained by sectioning was polished sequentially under water cooling with \# 400-, 600- and 1200-grit SiC papers.

Indentations and microhardness measurements (KHN) were performed sequentially in a microhardness tester(HMV-2000; Shimadzu, Tokyo, Japan). The direction of indentations was changed from one sequence to another. Indentations were performed at 100, 500 and $900 \mu \mathrm{m}$ from top surface (Fig. 1) with a $50 \mathrm{gf}$ load

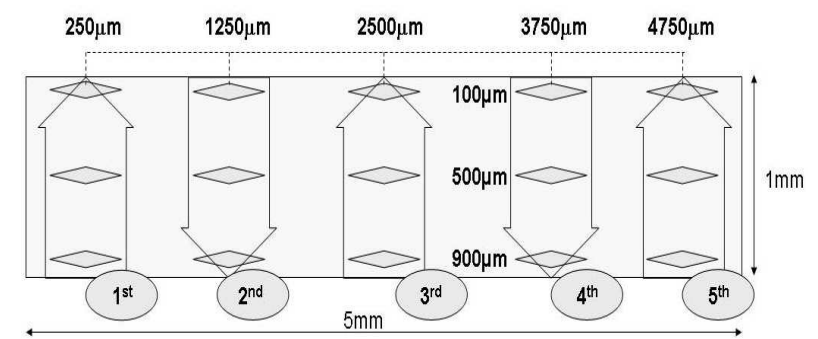

Figure 1. Schematic illustration of the sequence of Knoop hardness indentations. 
during $15 \mathrm{~s}$.

For each specimen, a mean value was obtained from 15 measurements and data were submitted to three-way ANOVA and Tukey's test $(\alpha=0.05)$.

\section{RESULTS}

There were statistically significant differences among the groups $(p<0.05)$. Tukey's test showed that, at all depths, the resin cement presented higher Knoop hardness means for QTH and LED compared to PAC and control group $(\mathrm{p}<0.05)$. The PAC group showed lower hardness means compared to the control group $(p<0.05)$, except for the middle region (Table 1). For QTH and LED, only the bottom region showed lower hardness means $(p<0.05)$. The control group presented similar hardness means at all depths $(p>0.05)$. For teh PAC group, the middle region showed higher hardness means compared to the bottom region, and the top surface showed intermediate hardness means.

\section{DISCUSSION}

The results on Table 1 show that light curing with PAC had a negative influence on the hardness of Rely$\mathrm{X}$ resin cement (lower values) compared to light curing with QTH and LED and control group. Thus, the null

Table 1. Comparison of hardness means (KHN) at the evaluated depths.

\begin{tabular}{llll}
\hline Treatment & Top & Middle & Bottom \\
\hline QTH/HeraCeram & $\begin{array}{l}49.22 \\
(5.41) \mathrm{A}, \mathrm{a}\end{array}$ & $\begin{array}{l}46.21 \\
(4.13) \mathrm{A}, \mathrm{a}\end{array}$ & $\begin{array}{l}40.63 \\
(5.84) \mathrm{A}, \mathrm{b}\end{array}$ \\
& 47.52 & 46.02 & 39.87 \\
LED/HeraCeram & $(3.30) \mathrm{A}, \mathrm{a}$ & $(4.41) \mathrm{A}, \mathrm{a}$ & $(3.58) \mathrm{A}, \mathrm{b}$ \\
& & & \\
Chemical & 28.76 & 31.28 & 25.38 \\
& $(2.99) \mathrm{B}, \mathrm{a}$ & $(2.88) \mathrm{B}, \mathrm{a}$ & $(4,27) \mathrm{B}, \mathrm{a}$ \\
PAC/HeraCeram & 21.93 & 25.36 & 18.16 \\
& $(2.30) \mathrm{C}, \mathrm{ab}$ & $(2.11) \mathrm{B}, \mathrm{a}$ & $(2.93) \mathrm{C}, \mathrm{b}$ \\
\hline
\end{tabular}

Different uppercase letters in the columns and lowercase letters in the rows indicate statistically significant differences among groups $(\mathrm{p}<0.05)$. Standard deviations are presented in parentheses. hypotheses of this study were rejected.

Light curing with QTH and LED provided similar hardness in all evaluated regions. These outcome might be attributed to the fact that, because of the short exposure time to PAC light, low energy density is delivered to the resin cement (13). This low energy leads to a low degree of conversion of the cement, determined indirectly by hardness measurements (14). It may be hypothesized that an increase in light exposure time would provide to similar hardness values to those obtained with QTH and LED, as observed with resin composite resins (3). Light curing with PAC would be even better for resin cement because its high emitting light intensity, which would be less attenuated by the veneering material compared to QTH and LED. The results of this study are in agreement with those of Rasetto et al. (4). On the other hand, Ozyesil et al. (15) found similar degree of conversion of Variolink II resin cement light cured with conventional QTH and PAC.

Light curing with PAC resulted in the lowest hardness values, even compared to cement setting by chemical reaction alone (Table 1). These low hardness means could be a result of light attenuation by the veneering material or the resin cement itself $(3,16)$. Another hypothesis is that light curing with PAC through HeraCeram induced the initiation of polymerization reaction, characterized by cross-linking formation, which could have reduced monomer mobility in the bulk mass, hindering the completion of cure by the chemical mode (17). In regions submitted to low energy density, the polymer chain would be more linear with higher mobility and lower hardness values.

Cementation using dual-cure resin cements has been indicated due the chemical initiators that would, theoretically, guarantee a reliable polymerization even with deficient light activation $(18,19)$. Peutzfeldt $(20)$ have reported that, when dual-cure cements are adequately light cured there is an increase of the conversion degree and ultimate mechanical properties are obtained compared to dual-cure cements submitted exclusively to chemical activation. This behavior was also observed in this study. In deeper regions, where less light is delivered, lower hardness was recorded (Table 1).

Additional studies should be conducted to further evaluate light curing through indirect prosthetic materials and determine which would be a reasonable light exposure time with PAC LCUs for dual-cure 
cement polymerization.

\section{RESUMO}

Este estudo avaliou, por meio do teste de dureza Knoop, a profundidade de polimerização do cimento resinoso dual (Rely$\mathrm{X}$ ) ativado quimicamente (grupo controle) ou química/fisicamente (dual), fotoativado através de uma faceta de cerâmica com $1,5 \mathrm{~mm}$ de espessura (HeraCeram). Incisivos bovinos tiveram sua face vestibular planificada e hibridizada. Sobre esta superfície, uma matriz de borracha ( $5 \mathrm{~mm}$ de diâmetro e $1 \mathrm{~mm}$ de altura) foi preenchida com cimento. Uma tira de poliéster ou um disco de material de faceta foi assentado sobre essa matriz. No grupo dual, a fotoativação foi realizada com aparelho de lâmpada halógena convencional (XL2500), por 40s (QTH); luz emitida por diodos (Ultrablue Is), por 40s (LED); ou por luz emitida por arco de plasma de Xenônio (Apollo 95E), por 3s (PAC). No grupo controle, a presa do cimento ocorreu somente por ativação química. Após armazenamento em ambiente seco e escuro $\left(24 \mathrm{~h} / 37^{\circ} \mathrm{C}\right)$, as amostras $(n=5)$ foram seccionadas para mensuração dos valores de dureza $(\mathrm{KHN})$ em três diferentes profundidades, obtidos em um aparelho microdurômetro $(50 \mathrm{gf} / 15 \mathrm{~s})$. Os dados foram submetidos à análise de variância e ao teste de Tukey $(\mathrm{a}=0,05)$. $\mathrm{O}$ cimento Rely-X apresentou maiores valores de dureza Knoop após fotoativação com QTH e LED, comparados ao grupo controle e PAC. A fotoativação com PAC resultou em valores de dureza inferiores ao grupo controle. A dureza do cimento foi menor em regiões mais profundas.

\section{REFERENCES}

1. Stappert CF, Guess PC, Chitmongkolsuk S, Gerds T, Strub JR. All-ceramic partial coverage restorations on natural molars. Masticatory fatigue loading and fracture resistance. Am J Dent 2007;20:21-26.

2. Fabianelli A, Goracci C, Bertelli E, Davidson CL, Ferrari M. A clinical trial of Empress II porcelain inlays luted to vital teeth with a dual-curing adhesive system and a self-curing resin cement. J Adhes Dent 2006;8:427-431.

3. Tango RN, Sinhoreti MA, Correr AB, Schneider LF, Kimpara ET, Correr-Sobrinho L. Knoop hardness of dental resin cements: Effect of veneering material and light curing methods. Polymer Test 2007;26:268-273.

4. Rasetto FH, Driscoll CF, von Fraunhofer JA. Effect of light source and time on the polymerization of resin cement through ceramic veneers. J Prosthodont 2001;10:133-139.

5. O'Keefe KL, Pease PL, Herrin HK. Variables affecting the spectral transmittance of light through porcelain veneer samples. J Prosthet Dent 1991;66:434-438.
6. Arrais CA, Giannini M, Rueggeberg FA, Pashley DH. Microtensile bond strength of dual-polymerizing cementing systems to dentin using different polymerizing modes. J Prosthet Dent 2007;97:99-106.

7. Filipov IA, Vladimirov SB. Residual monomer in a composite resin after light-curing with different sources, light intensities and spectra of radiation. Braz Dent J 2006;17:34-38.

8. Correr AB, Sinhoreti MA, Correr Sobrinho L, Tango RN, Schneider LF, Consani S. Effect of the increase of energy density on Knoop hardness of dental composites light-cured by conventional QTH, LED and xenon plasma arc. Braz Dent J 2005;16:218-224.

9. Tanoue N, Koishi Y, Matsumura H, Atsuta M. Curing depth of different shades of a photo-activated prosthetic composite material. J Oral Rehabil 2001;28:618-623.

10. Darr AH, Jacobsen PH. Conversion of dual cure lutting cements. J Oral Rehabil 1995;22: 43-47.

11. Rueggeberg FA, Caughman WF, Curtis JW, Jr. Effect of light intensity and exposure duration on cure of resin composite. Oper Dent 1994;19:26-32.

12. Witzel MF, Braga RR, Singer J de M, Azevedo CL. Bond strength between polymer resin-based cement and porcelaindentin surfaces: influence of polymerization mode and early cyclic loading. Int J Prosthodont 2003;16:145-149.

13. Obici AC, Sinhoreti MA, Correr Sobrinho L, Goes MF, Consani S. Evaluation of depth of cure and Knoop hardness in a dental composite photo-activated using different methods. Braz Dent J 2004; 15:199-203.

14. Sharkey S, Ray N, Burke F, Ziada H, Hannigan A. Surface hardness of light-activated resin composites cured by two different visible-light sources: an in vitro study. Quintessence Int 2001;32:401-405.

15. Ozyesil AG, Usumez A, Gunduz B. The efficiency of different light sources to polymerize composite beneath a simulated ceramic restoration. J Prosthet Dent 2004;91:151-157.

16. Knezevic A, Tarle Z, Meniga A, Sutalo J, Pichler G, Ristic M. Photopolymerization of composite resins with plasma light. J Oral Rehabil 2002;29:782-786.

17. Soh MS, Yap AU. Influence of curing modes on crosslink density in polymer structures. J Dent 2004;32:321-326.

18. Kramer N, Lohbauer U, Frankenberger R. Adhesive lutting of indirect restorations. Am J Dent 2000;13:60D-76D.

19. Rahiotis C, Kakaboura A, Loukidis M, Vougiouklakis G. Curing efficiency of various types of light-curing units. Eur J Oral Sci 2004;112:89-94

20. Peutzfeldt A. Dual-cure resin cements: in vitro wear and effect of quantity of remaining double bonds, filler volume, and light curing. Acta Odontol Scand 1995;53:29-34.

Accepted April 17, 2007 